\title{
The Korean Media in Los Angeles: Their Role in the Multicultural Society
}

\author{
Jin-Young Kim \\ Kangwon National University, 1 Kangwondaehak-gil, \\ Chuncheon-si, 200-701, Gangwon-do, Korea \\ staci21@naver.com
}

\begin{abstract}
The Korean media in LA have come a long way to help Koreans adapt to American society and at the same time, to provide them with necessary information to understand current issues in Korea almost simultaneously. Also, as LA Koreatown is the largest Korean community overseas, the Korean media in LA play a crucial role to bridge the gap between the generations and between Korea and America. Even though, many Korean media tend to work in poor condition and lack of experienced employees compared to the mainstream media, they take responsibilities for immigrants who were usually exempted from the whitepredominant media by customizing the news and information for the Korean community. As of 2010, the Overseas Korean Foundation Support Act was enacted in Korea. Accordingly, the Act insures that the government supports overseas Korean media in a variety of fields with technical as well as financial support. In this context, despite of growing concerns about possible constriction of freedom of speech, the Korean media in LA definitely enter a new epoch.
\end{abstract}

Keywords: Korean media, LA Koreatown, the Overseas Korean Foundation Support Act, diaspora, immigrant

\section{Introduction}

Los Angeles (LA hereunder) is the gate of Korean immigrants to US and occupies core position among Koreans in US. According to census in 2010, Koreans residing in LA County were 210,866, recording the third biggest population following Chinese and Filipino. It was $16 \%$ higher than 186,350 in 2000 and 8.6\% growth from 199,221 in census in 2011 published on 'The American Community Survey.' Given the number of Korean residing in whole California (around 450,000) more than half of Koreans in California live in LA County. From this perspective, we can say LA County is the center of Korean Community in California.

LA Koreatown is the place where Koreans make economic activities most actively as if it tried to show the supports for the aforementioned statement. It diffuses Korean culture to the mainstream society in US and provides a place of exchange so that 2nd generation Koreans can keep their cultural identity. In early 1970s, Korean who gathered in southern suburbs falling behind of the development in LA made advancement to Mid-Wilshire which was filled with high-rise buildings were in a few decades. They built a model ethnic town there. Koreatown officially designated by the City of LA includes only 7 square meters near Olympic Road but the actual Koreatown can be extended farther as there are many Korean shops in the area a little bit far from Olympic Road. There have been many ups and downs in Koreatown to be what it is now. In particular, LA Riot in 1992 tremendously damaged 
Korean society. But it also became an opportunity for Korean society to nurture competencies of the community through political enlightenment and to enforce the communication with mainstream of the States and other minor ethnic communities.

Although there were official institutions such as The Korean Consulate General in LA and Association of Korean Residents, they could not function well as a control tower in such emergency. At that time what prevented human life loss of Koreans and played decisive roles in aftermath was Korean media including Radio Korea. At present, people can watch, read or listen to Korean news through Internet or SNS in real time but the popularity of conventional media such as radio, newspaper and TV stations did not get lowered in conservative society of immigrants. They made total directional influences on Korean society by composing opinions on political and social issues, providing legal knowledge and educational programs to help them to live a successful immigrant's life and facilitating communication between generations and classes through planning festivals and travel programs as well as information delivery, the inherent role of media.

Additionally, as political rights of Korean in overseas were recognized in 2012, political participation of overseas Koreans is getting more activated. With the activated participation, the roles and responsibilities of Korean media are expected to increase. Accordingly, in this study, it was tried to review the current status and roles of media which make active activities in LA where the biggest Korean population lives and to view future tasks.

\section{The Aspects of Ethnic Media}

Unlike mainstream media, many small to medium sized ethnic media operators find difficulty in retaining staff to develop human resources and management potential. This negatively impacts effective organizational growth that the employees perceive their jobs in small to medium ethnic media companies as a first step to a career with a larger media organization [1].

Thus, it is difficult to secure proper human resources, leading to reporting limited news usually happening in their ethnic boundary. According to Lin and Song (2006) More than half (55\%) of the total Los Angeles ethnic media news was international, and $80 \%$ of that focused on the "home" country. On the other hand, they dedicated only $4 \%$ to neighborhood stories. However, ethnic media do not seem to help boost immigrants' adaptation to a mainstream society, they positively manifest distinctive characteristics.

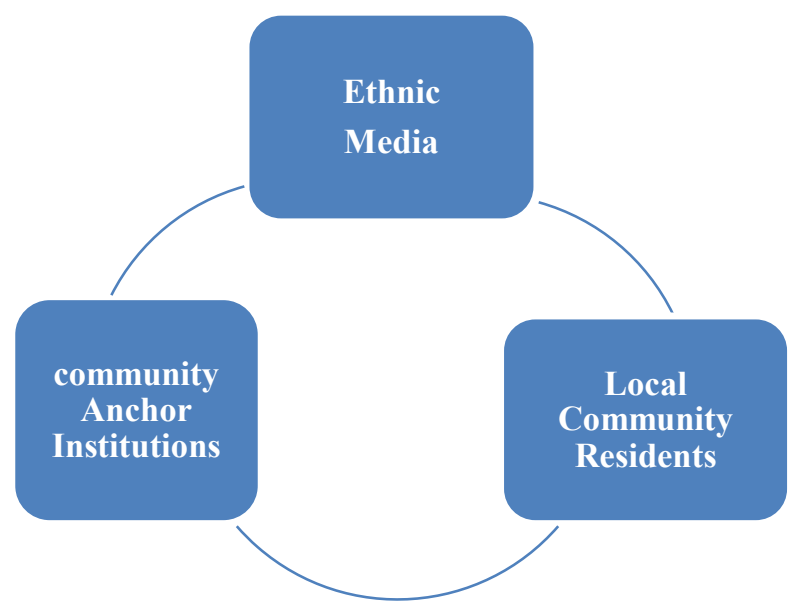

Figure 1. Communication Network of Well-connected Community 
As shown in Figure 1, when ethnic media are connected with community organizations and encourage residents' connections with those organizations by publicizing their events and services, these media also strengthen their own relationships with residents by connecting them with dependable information. The Metamorphosis Project at the University of Southern California has consistently found that residents in communities where ethnic media, community organizations, and residents are all linked to each other report a greater sense of community belonging and find it easier to access local resources related to civic engagement, health information, and community news [2].

\section{The Status of Ethnic Korean Media}

\subsection{The Korea Times and the Joongang Daily}

As the rate of newspaper subscription is decreasing, the newspapers particularly in ethnic communities still remain very influential in political decision-making. [3]. That may be attributed to informing the public on politics including the emphasis on quality in newspaper articles, the larger space available to provide readers more depth, and the more leisurely way that voters consume information, allowing for mature cognitive processing [3].

While daily newspapers such as the Chosun Ilbo(Daily), the Joongang Ilbo and the Dong-A Ilbo have substantial influence in Korea, the Korea Times has the largest circulation among those published in LA. The Korea Times LA branch, which was the U.S. distribution arm of the Hankook Ilbo, one of the largest newspapers in Korea, started to report local news in a small building in Studio City located in northwest part of Los Angeles in 1969 when Koreatown had not been established yet. It means it entered the US market earlier than other newspapers. They copied 4 out of 6 pages of the Hankook Ilbo published in Seoul by getting them via air. The newspaper gained feverous welcome from Korean people as a passage delivering news of their home country consoling the tiring immigrants' lives. Thanks to these zealous reactions, it has published a local edition since 1970. As it grew, it came to have company headquarters on Wilshire Boulevard, the road of luxurious buildings.

The Korea Times has branches in New York, Washington, San Francisco, Chicago, and Hawaii as well as head quarter in LA. When analyzing editorials from July 13 to September 14 in 2012, it was found that there were campaign articles with political intention such as encouraging electorate registration for coming presidential election, asking readers to pay attention to elections in US, and emphasizing the necessity of reorganization of LA electoral districts, and information to help new immigrants to live a stable life such as raids of Labor Authority and introduction of illegal immigrants' certificate. The mainstream of editorials was to materialize public good through the participation in coin sharing movement and establishment of monument of comfort women in LA.

The Joongang Daily is a newspaper competing with the Korea Times in LA. Its LA branch established in 1974 and has played a role of bridging Korean society with the mainstream. As of 2013, it has 10 branches in the cities in North America such as Honolulu, Seattle, New York, and Washington and delivers news to approximately 2 million subscribers. The Joongang Daily provides broad information including education and laws by introducing "Hananet Free Phone Directory Service", which appears to be one-stop consulting services. Additionally, it has signed the agreements not only with the Korean HQ but also with the overseas media groups in US, UK, France and Japan and constructs an exclusive news supply system. The Joongang Daily in LA dealt with hot issues in depth that had not been chosen by conservative writers at the Headquarters in Korea such as an exclusive interview with 'Whatbecomes' who was known as the operator of the internet cafe dubbed 'Tajinyo (We 
Request Truth to You, Tablo.)' related to a Korean-Canadian hip-hop singer Tablo who made a sensation in Korean society in 2010, and published an editorial criticizing the new government's Creative Economy policy or Lieutenant Kim Hoon accident. ${ }^{1}$ Based on editorials and opinion sections for a month of April in 2013, Korea related news were not more than $10 \%$ in average. In April, the threatening of North Korea related to nuclear weapons was at its peak, and nearly half of the news was about North Korea related news from Korea.

The Korea Times and the Joongang Daily published editorials to improve the political position and to maximize the influence of Korean society, and allotted much space for the information for new immigrants with the enforcement of law regarding illegal immigration. It shows that Korean assimilated to the mainstream society subscribe major newspapers while newly arrived immigrants who are not good at English tend to be a subscriber of the Korean newspapers. Regardless of the trend that the number of newspaper subscribers is decreasing because of TV and new media like SNS and other internet portal news, the status of these two newspapers is still high in Korean Society in LA. The popularity of Korean newspapers including the two has continued to increase and they reached about 64 percent of their adult populations in the United States [4].

Table 1. The Major Korean Media in LA

\begin{tabular}{|l|l|}
\hline \multicolumn{1}{|c|}{ Media Specification } & \multicolumn{1}{c|}{ Name of organization } \\
\hline Newspaper & The Hankook Ilbo \\
\hline Newspaper & The Joonang Ilbo \\
\hline Newspaper & The Herald Economy \\
\hline Weekly magazine & The Sunday Journal \\
\hline Weekly magazine & TheWeekly Entertainment \\
\hline TV & KBS-LA \\
\hline TV & KTAN TV \\
\hline TV & TVK24 \\
\hline TV & Hanmi TV \\
\hline Radio & Radio Korea \\
\hline Radio & Radio Seoul \\
\hline
\end{tabular}

\subsection{The Sunday Journal}

Sunday Journal is a weekly journal which relies on Korea readers in LA and Orange County since its establishment in 1982. It is a weekly news magazine major areas of interest of which includes all areas such as politics, economics, social things, community news, sports and entertainment. It has 28,000 readers and posts many articles regarding Korean politics unlike major daily newspapers in LA. On the other hand, in business section, news directly related to Korean society such as trend of stock market in US and economic index is introduced, and in culture and social section, issues and problems in Korean society are analyzed or reported critically.

Yeon Hoon, the publisher and editor of this weekly magazine is known as a man of antigovernment inclinations under the past military governments. In 1988, he was arrested and

\footnotetext{
1 He was a first lieutenant who was found mysteriously shot at the Joint Security Area demilitarized zone in
} 1998. 
was brought into custody by Prosecutors when he visited Korea to collect news. At that time he was accused of the series of articles dealing with the improper relationship between a large enterprise owner family and Sun Myung Moon of the Unification Church in 1987. The magazine had suspended publication for a while because of those secret revealing articles. Recently, the Sunday Journal wrote about the investigation of prosecutors on MB's presidential election fund in 2012 and raised negative speculation over Ahn Cheol-soo. ${ }^{2}$

Although this magazine is a medium in Korean society in US, it has noticeably focused on domestic issues as much as domestic magazine. In August in 2012, it was accused of the article criticizing private life of Park Geun-hye presidential candidate and the article was deleted. The Sunday Journal has been in the middle of controversy constantly. As such, it is a Korean journal based on US that acknowledges freedom of media unlike Korean media which are prone to being influenced by power topography in politics. Therefore, it is inclined to publish articles according to private ideology and faith.

\subsection{The KoreAm Journal}

The KoreAm is an English monthly magazine founded in 1992 that covers and analyzes the news, culture, entertainment, sports, politics and Korean Americans. In addition to featuring the most talked-about stories from Korean-American community, it delivers timely news updates, hosts exclusive web interviews and giveaways, and serves as a vibrant online community for everyone interested in the Korean-American experience. Unlike Sunday Journal, this magazine mainly targets not only on Korean Americans but also other races by providing articles only in English. The online category, "I Am KoreAm." that enables visitors to introduce themselves and write the stories is very unique. In addition, the company has held the luxurious event, "Unforgettable" since 2003 to award Korean American celebrities from a variety of fields. This magazine company itself was awarded by New America Media called the Pulitzer Award for minorities, emerging as a representative Korean English-based media that bridges the gap between the generations.

\subsection{Radio Korea}

The most important goals of the ethnic media are to give voice to their communities, to strengthen cultural pride and provide cultural cohesion [5]. Radio broadcasting may be considered less popular than TV, yet, LA, where many citizens commute to work by car, has a different aspect. According to the California Department of Motor Vehicles, there are a total number of 1,977,803 automobiles in the city. According to 2005 U.S. Census data, all but 7.8\% live in households where at least one car is available. $25.2 \%$ of them live in households where there are 3 or more cars available. Consequently, the average one-way commute to work for people living in L.A. County was 29.4 minutes, while the average commute nationally was 25.5 minutes [6]. Do the more cars and commuters mean the more listening to radio? The answer is yes. A report conducted by Edison Media Research in April, 2013, 84\% of all people over 12 who have been in a car over the past month reported listening to AM or FM radio in the car. About $60 \%$ of the commuters listen to the radio while driving. Also, this report indicates that radio is a very effective advertising medium as online radio listening grows rapidly, Thus, it is not overstated that radio is still popular and desired in 2013, which clearly contradicts what some in other media insist [7].

2 He was a presidential candidate in 2012. As of April, 2013, Ahn Cheol-soo won the Nowon district by-election in Seoul by a wide margin as an independent candidate. 
In this context, Radio Korea is one of media influencing opinions in Korean society according to characteristics of life in US where most of which should spend much time in commuting. Radio Korea was established in LA in 1989 and acquired audience by broadcasting life information and immigration knowledge for Koreans residing in South California. The current status of this company owes to LA Riot on April 29, 1992. Koreans who were mostly self-employers in black condensed area running liquor store or mart became victims of plunder and arson. Korean society that was shunned by mainstream broadcasting companies had to depend on special programs of Radio Korea and tried to find the way of restoration.

President George Bush visited Radio Korea with concerned people after the riot was settled and praised its performance during the riot. With the pains of LA Korean society, Radio Korea has grown to be what it is now and it is broadcasting 24 hours a day and 12 branches in US. It became the biggest Korean media in US. It made an agreement with LA Dodgers and has broadcasted games of Korean pitchers such as Park Chan-ho and Ryu Hyun-jin on live. Radio Korea also has an exclusive contract with YTN and Yonhap News in Korea and has RK TV Broadcasting as a subsidiary company focusing on the second generation Koreans in US. Radio Korea has broadcasted for 24 hours a day via internet for the first time among overseas Korean media since 1996. Besides, it provides various contents for online platforms including portal and social commerce.

\section{Conclusion}

Ethnic communities in America have been considered to develop within the boundaries of geographical neighborhood and cultural background to a certain degree. However, technological mediation characterized by ethnic media pulls down the realm of communities and organizes immigrants and objects across distance. As Appadurai called mediascape 'imagined worlds', the ethnic media are constituted by the historically situated imaginations of diaspora spread around the globe [8].

The Korean media in LA have come a long way to help immigrants catch up with Korea's political and socio-cultural climate. In return, the Korean government has enacted the Overseas Korean Foundation Support Act in 2010 to implement a variety of policies focused Korean residents and their organizations abroad. This Act insures that the government supports the programs and publicizes events conducted and planned by overseas Korean residents by law. In addition to that, the government secures scholarships for Korean descendents overseas.

Accordingly, despite of growing concerns about possible arrogations of freedom of speech, some of the Korean media in poor working conditions can be able to find a way to get support from the Korean government, leading to various voices of Korean communities in LA.

\section{References}

[1] G. A. Huston, "A national socio-economic report on Canada's community-based ethnic/third language media", National Ethnic Press and Media Council of Canada, (2012).

[2] V. S. Katz, M. D. Matsaganis and Ball-Rokeachefthnic, "Media as Partners for Increasing Broadband Adoption and Social Inclusion", Journal of Information Policy, vol. 2, (2012), pp. 79-102.

[3] J. N. Druckman, "Media matter: How newspapers and television news cover campaigns and influence voters", Political Communication, vol. 22, no. 4, (2005), pp. 463-481.

[4] New America Media, "A National Study on the Penetration of Ethnic Media in America", (2009), pp. 3.

[5] L. A. Cristina, "The Health of Ethnic Media: Needs and Opportunities", The McCormick Foundation report, (2008), pp. 2.

[6] The City of Los Angeles Transportation Profile, (2009), pp. 1-29. 
[7] T. Webster, “The Infinite Dial 2013: Navigating Digital Platforms", Edison Media Research, (2013).

[8] A. Appadurai, "Disjuncture and Difference in the Global Cultural Economy", in Modernity at Large: Cultural Dimensions of Globalization, Minneapolis: University of Minnesota Press, (1998), pp. 27-47.

\section{Author}

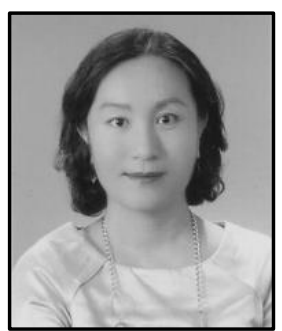

\section{Jin-Young Kim}

She has received her PhD in Cultural Contents at Hankuk University of Foreign Studies. She is now working as a visiting lecturer at Kangwon National University and HUFS. Her academic interests include ecomuseum, rural development and urban revitalization, and multiculturalism. 
International Journal of Multimedia and Ubiquitous Engineering Vol.8, No.6 (2013) 